\title{
Clinical Reasoning: A 64-Year-Old Man With History of Meningitis Presenting With Proximal Weakness of the Arms
}

Philipp Karschnia, MD, DSc, Leon Kaulen, MD, Niklas Thon, MD, DSc, MBA, and Joachim M. Baehring, MD, DSc

Neurology ${ }^{\circledR}$ 2022;98:208-213. doi:10.1212/WNL.0000000000013085
Correspondence

Dr. Baehring

joachim.baehring@yale.edu

\begin{abstract}
A 64-year-old man presented for evaluation of proximally pronounced weakness of the arms with preserved facial and lower extremity strength. Symptoms slowly developed over the last 2 years, and the patient's history was notable for severe Listeria monocytogenes meningitis 4 years before presentation, which was adequately treated with antibiotics. On examination, symptoms clinically reassembled man-in-the-barrel syndrome and localized to the cervicothoracic central cord. Blood analysis was unremarkable, and CSF analysis showed no recurrent or persistent infection. Spinal MRI revealed pockets of sequestered CSF from C3 to C4 and areas of CSF space effacement from $\mathrm{C} 3$ to T12. MRI findings were interpreted as cord tethering suggestive of adhesive arachnoiditis. CT myelogram showed insufficient contrast agent migration above T10 and contour irregularities of the conus medullaris, confirming the postulated pathomechanism of cord tethering. Final diagnosis was therefore cervicothoracic central cord damage due to cord tethering in the setting of postinfectious adhesive arachnoiditis following bacterial meningitis. The patient failed a course of pulsed methylprednisolone therapy, and symptoms progressed. Best supportive care was provided. The clinical presentation of adhesive arachnoiditis is variable, and advanced imaging techniques and invasive studies such as CT myelogram may be required to establish the diagnosis. Timely diagnosis is warranted as early surgical or medical therapy can improve symptoms.
\end{abstract}

From the Department of Neurology (P.K., L.K., J.M.B.); and Department of Neurosurgery (P.K., J.M.B.), Yale School of Medicine, New Haven, CT; Department of Neurosurgery (P.K., N.T.), Ludwig-Maximilians-University Munich; and Department of Neurology (L.K.), Heidelberg University Hospital, Germany.

Go to Neurology.org/N for full disclosures. Funding information and disclosures deemed relevant by the authors, if any, are provided at the end of the article. 


\section{Section 1}

A 64-year-old man presented for evaluation of bilateral upper limb weakness. Two years prior, the patient noticed burning dysesthesias in his left shoulder associated with inability to lift his arm up to the steering wheel. Symptoms slowly progressed and soon involved his right arm following a similar pattern. Moreover, he described a band of painful dysesthesias around his chest aggravated by physical activity and shooting pain from the neck down when sneezing.

His history revealed Listeria monocytogenes meningitis 4 years before presentation, which was diagnosed by PCR from CSF, manifested as depressed sensorium, and resulted in ICU treatment. Brain and spine MRI was unremarkable at the time. Symptoms resolved after a 5-week course of IV administered antibiotics ( 2 weeks of ampicillin combined with gentamicin, followed by 3 weeks of ampicillin). His medical history was otherwise remarkable for hyperlipidemia and myocardial infarction. No trauma, alcohol abuse, or smoking was reported.

General examination was unremarkable. On neurologic evaluation, there were no cranial nerve deficits. Fasciculations were noted in the deltoid and biceps brachii muscles, and atrophy of the hypothenar more than thenar muscles was present particularly in the left hand. Confrontational strength testing of his upper extremities revealed profound bilateral deltoid weakness $(1 / 5)$. More distal arm muscles were less affected (biceps: $2 / 5$ left, $4 / 5$ right; triceps: $3 / 5$ left, $5 / 5$ right; wrist flexion and extension: $3 / 5$ bilaterally; grip: $3 / 5$ left, $4 / 5$ right; finger flexion (DII-IV): $4 / 5$ bilaterally; dorsal interossei muscles: $0 / 5$ left, $3 / 5$ right). There was no weakness in the lower extremities. Deep tendon stretch reflexes were absent (grade 0 ); muscle tone was decreased in the arms, and tone as well as deep tendon stretch reflexes were markedly increased in the legs (grade 3+). There were segmental sensory deficits with loss of temperature perception in the trunk (level: T2-T10 left, T4-T12 right) and mild perineal and lower leg numbness without loss of temperature perception. The patient indicated intermittent difficulty initiating micturition. Gait was steady.

\section{Questions for Consideration:}

1. Where would you localize the patient's neurologic symptoms?

2. Which neurologic clinical syndrome do the presenting symptoms resemble?

3. What are possible etiologies for the patient's syndrome?

GO TO SECTION 2 


\section{Section 2}

The patient presented with proximally pronounced motor impairment of the arms and sensory impairment of the trunk, whereas cranial nerves and lower extremity function were largely preserved. The symmetric proximal motor deficits combined with absent reflexes and fasciculations in the arms pointed toward lower motor neuron involvement. Long tract signs as demonstrated by hyperreflexia in the legs, increased leg muscle tone, and bladder dysfunction pointed toward corticospinal tract damage at the cervicothoracic level. Asymmetrical sensory deficits of the trunk with suspended sensory loss suggested thoracic spinal cord involvement or less likely peripheral nerve involvement. We concluded that symptoms may localize to the cervicothoracic central cord with accentuation at the lower cervical cord because of motor neuron involvement at these levels.

Bilateral paresis of the proximal upper extremities with preserved facial and lower extremity strength is denoted by the term man-in-the-barrel syndrome. ${ }^{1}$ This condition has been described in 2 classical scenarios allowing topical diagnosis. First, man-inthe-barrel syndrome was described following cerebral hypoperfusion resulting in bilateral watershed infarctions between anterior and middle cerebral artery territories. ${ }^{1}$ Second, central spinal cord pathologies such as spinal cord infarction resulting in injury to anterior horn cells may give rise to such symptoms. ${ }^{2}$ Less common causes involve other cerebral pathologies (e.g., metastases), pontine damage (e.g., central pontine myelinolysis), anterior horn cell disease (e.g., ALS), bilateral brachial plexopathies, polyradiculopathies, myopathies, neuromuscular junction disorders, or muscle-related pathologies (e.g., paraneoplastic, inflammatory, or drug-induced myopathies). ${ }^{2}$

Given potential involvement of the cervicothoracic central cord in our case with suspended sensory loss and relative preservation of long tract function, a rather extensive but localized process involving multiple spinal cord segments, such as infiltrative cord neoplasms or traction-related myelopathy from adhesive arachnoiditis, was believed to be most likely. We also considered nutritional deficits including vitamin B12 deficiency and disorders of copper or zinc metabolism. Spinal cord ischemia was less likely given the absence of symptom correlation with vascular territories, but a perfusion-related deficit resulting from a dural arteriovenous malformation could not be excluded. The time course was not consistent with acute myelitis.

\section{Questions for Consideration:}

1. Which tests would you include in your initial diagnostic workup?

2. Does the history of meningitis influence the testing you want to pursue? 


\section{Section 3}

A blood analysis was performed to exclude a systemic inflammatory process, nutritional deficits, metabolic disorders, or an immunocompromised state. A lumbar puncture was obtained to rule out chronic infectious or neoplastic meningeal processes. The possibility of intrinsic neoplasms or vascular malformations was evaluated by cervicothoracic spine MRI (Figure, B and D). Results were compared with previous imaging studies performed after treatment for meningitis (Figure, $\mathrm{A}$ and $\mathrm{C}$ ).

Blood analysis (including complete blood count, comprehensive metabolic panel, antinuclear antibody screen, erythrocyte sedimentation rate, serum protein and immunofixation electrophoresis, thyroid-stimulating hormone, creatine kinase, aldolase, vitamin B12, vitamin E, folate, copper, rapid plasma reagin, Lyme, and HIV serology) was unremarkable. Although CSF analysis showed mildly elevated protein levels, there were no signs of active viral or bacterial infections on the CSF cell count, microscopy, culture, or PCR. No neoplastic cells were seen on CSF microscopy. Spinal MRI revealed pockets of sequestered CSF from C3-C4 resulting in cord compression (Figure, B and D). Areas of CSF space effacement around the spinal cord suggestive of cord tethering were seen from C3-T12. Intrinsic spinal cord signal on T2weighted sequences was increased from $\mathrm{C} 3$ to conus medullaris on T12, most prominent in the gray matter giving rise to a snake-eye appearance (Figure, D). ${ }^{3}$ There was subtle diffuse dural contrast enhancement.

Given the patient's history of infectious meningitis, the radiographic findings were interpreted as adhesive arachnoiditis with cord tethering resulting in man-in-the-barrel syndrome. To verify the postulated pathomechanism, CT myelogram of the thoracolumbar spine was performed (Figure, E). Although the contrast agent entered the thecal sac, no contrast agent migrated above T10. After repetitive patient placement in the Trendelenburg position, only a small amount of contrast agent ascended along the ventral median sulcus of the cord. Contour irregularities of the conus medullaris were consistent with spots of cord tethering.

\section{Questions for Consideration:}

1. How is bacterial meningitis, in particular from Listeria monocytogenes, treated?

2. How common is postinfectious adhesive arachnoiditis? Are there any means that help preventing this condition?

3. What are possible therapeutic approaches for the described pathology?

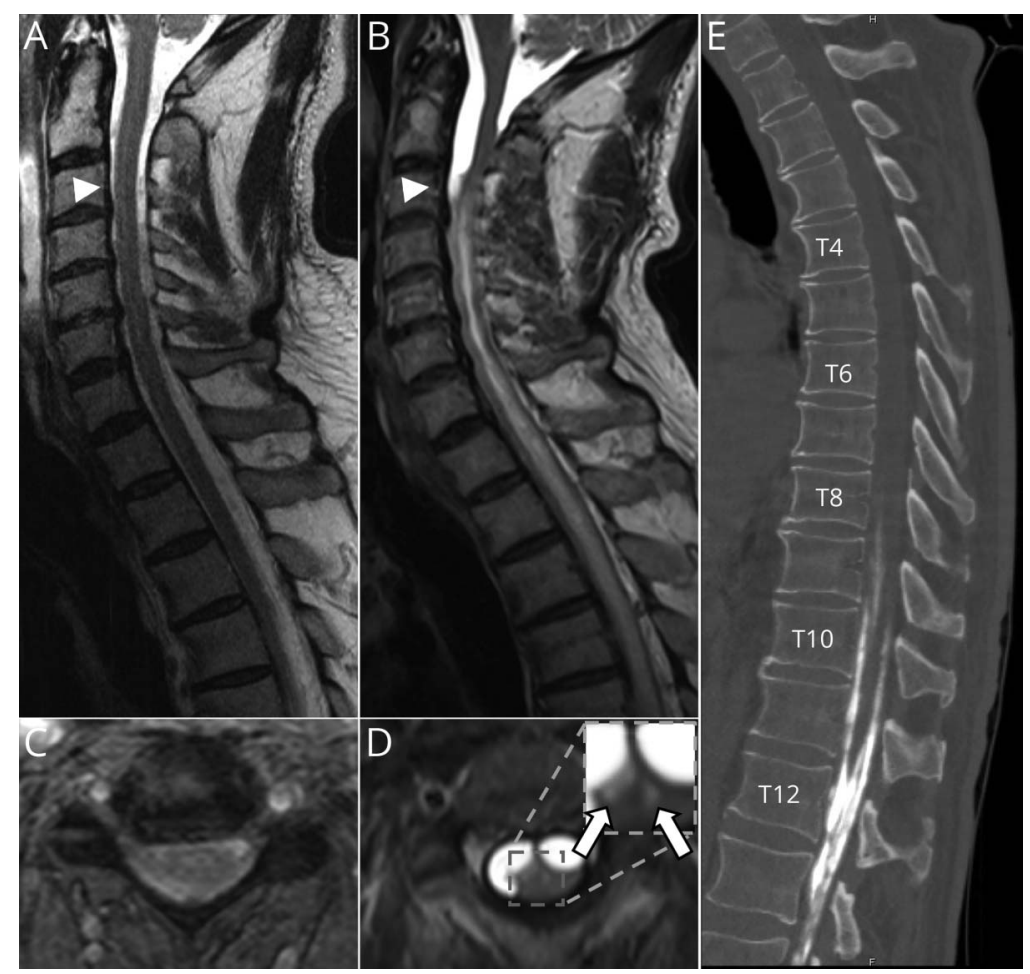

(A-D) Sagittal and axial T2-weighted MRI sequences performed during prior hospitalization for Listeria monocytogenes meningitis ( $A$ and $C$ ) and at first presentation for bilateral upper limb weakness 4 years later (B and $D)$. The level of the axial images (C) and (D) is indicated by arrow heads in (A) and (B). T2 hyperintense pockets of sequestered CSF at the level of C3 resulting in cervical cord compression are demonstrated (B and $D)$. The cord appears to be tethered to the dura by soft tissue-isointense bands consistent with adhesive arachnoiditis. Increased intramedullary T2 signal confined to the gray matter is noted in the central spinal cord at the level of C3 and below giving rise to a snakeeye appearance of the gray matter on axial sections (inlay and arrows in D). (E) Sagittal view of a CT myelogram shows the contrast agent entering the thecal sac and surrounding the distorted conus medullaris, but only a small amount of contrast agent migrates above the level T10 after Trendelenburg placement. The findings are highly suggestive of scarring of the arachnoid. 


\section{Section 4}

Bacterial meningitis can be divided into the more frequently encountered community-acquired meningitis and the less often encountered hospital-acquired meningitis. Streptococcus pneumoniae, group B Streptococcus, Haemophilus influenzae, Neisseria meningitidis, and Listeria monocytogenes are the most frequently found pathogens in community-acquired bacterial meningitis. ${ }^{4}$ Empiric antimicrobial therapy is recommended to include a combination of vancomycin, ampicillin, and a thirdgeneration cephalosporin like ceftriaxone. ${ }^{5}$ Directed antimicrobial therapy can be administered once the pathogen has been identified. Listeria monocytogenes harbors cephalosporin resistance; ampicillin is effective and may be combined with gentamicin. The treatment duration should be at least 3 weeks. ${ }^{6,7}$

Adjunctive dexamethasone therapy may improve neurologic outcomes from bacterial meningitis and prevent scar formation. ${ }^{5}$ However, adhesive arachnoiditis appears exceedingly rare even in the absence of dexamethasone. ${ }^{8,9}$

When progressive symptoms due to adhesive arachnoiditis and spinal cord traction in the postinfectious stage occur, neurosurgical adhesiolysis has been reported. ${ }^{9}$ In our patient, detethering was not deemed feasible because of the extent of cord tethering. Although systemic steroids can ameliorate symptoms, ${ }^{10}$ our patient failed a course of pulsed methylprednisolone. Epidural steroids may increase the risk of adhesive arachnoiditis rather than representing a promising therapy. ${ }^{11,12}$ One year after initial presentation, weakness in the arms progressed and gait became increasingly unsteady. Supportive care was provided using neuropathic pain medication.

\section{Discussion}

The final diagnosis was cervicothoracic central cord damage due to cord tethering in the setting of postinfectious adhesive arachnoiditis following bacterial meningitis, clinically giving rise to man-in-the-barrel syndrome.

Our patient presented with adhesive arachnoiditis 4 years after bacterial meningitis. We did not find evidence of recurrent or residual CNS infection in the CSF or blood. However, bacterial meningitis may induce sterile inflammation resulting in leptomeningeal scar formation that can lead to spinal cord traction. ${ }^{8,9}$ Other etiologies driving adhesive arachnoiditis include mechanical (e.g., trauma, spinal surgery, and lumbar punctures) or chemical (subarachnoid hemorrhage, intrathecal contrast dye, or anesthetics) causes of arachnoidea irritation, infections (e.g., tuberculosis, syphilis, and Lyme disease), autoimmune diseases (e.g., sarcoidosis), ${ }^{8}$ and very rarely potentially also genetic causes. ${ }^{13,14}$

Diagnosis of adhesive arachnoiditis was established through clinical, neurologic, and imaging findings. Notably, the clinical presentation is variable and determined by the affected cord level. Laboratory blood and CSF studies are nonspecific and mainly used to rule out other (e.g., infectious or autoimmune) causes of arachnoiditis. ${ }^{10,13,14}$ MRI often shows arachnoid cysts, nerve root clumping or enhancement, cord swelling, and arachnoid septations. ${ }^{8,15}$ Snake-eye cord appearance on imaging is nonspecific but may be prognostically unfavorable as it can represent cystic gray matter necrosis. ${ }^{3} \mathrm{CT}$ myelogram may assist in establishing diagnosis. Timely diagnosis is warranted as early therapy may improve outcome.

\section{Study Funding}

No targeted funding reported.

\section{Disclosure}

The authors report no disclosures relevant to the manuscript. Go to Neurology.org/ $\mathrm{N}$ for full disclosures.

\begin{tabular}{|c|c|c|}
\hline Name & Location & Contribution \\
\hline $\begin{array}{l}\text { Philipp } \\
\text { Karschnia, } \\
\text { MD, DSc }\end{array}$ & $\begin{array}{l}\text { Department of Neurology, } \\
\text { Yale School of Medicine; } \\
\text { Department of Neurosurgery, } \\
\text { Yale School of Medicine, New } \\
\text { Haven, CT; Department of } \\
\text { Neurosurgery, Ludwig- } \\
\text { Maximilians-University } \\
\text { Munich, Germany }\end{array}$ & $\begin{array}{l}\text { Drafting/revision of the } \\
\text { manuscript for content, } \\
\text { including medical writing for } \\
\text { content; major role in the } \\
\text { acquisition of data; study } \\
\text { concept or design; and } \\
\text { analysis or interpretation of } \\
\text { data }\end{array}$ \\
\hline $\begin{array}{l}\text { Leon } \\
\text { Kaulen, MD }\end{array}$ & $\begin{array}{l}\text { Department of Neurology, } \\
\text { Yale School of Medicine; } \\
\text { Department of Neurology } \\
\text { (L.K.), Heidelberg University } \\
\text { Hospital, Germany }\end{array}$ & $\begin{array}{l}\text { Drafting/revision of the } \\
\text { manuscript for content, } \\
\text { including medical writing for } \\
\text { content, and analysis or } \\
\text { interpretation of data }\end{array}$ \\
\hline $\begin{array}{l}\text { Niklas Thon, } \\
\text { MD, DSc, } \\
\text { MBA }\end{array}$ & $\begin{array}{l}\text { Department of Neurosurgery, } \\
\text { Ludwig-Maximilians- } \\
\text { University Munich, Germany }\end{array}$ & $\begin{array}{l}\text { Drafting/revision of the } \\
\text { manuscript for content, } \\
\text { including medical writing for } \\
\text { content, and analysis or } \\
\text { interpretation of data }\end{array}$ \\
\hline $\begin{array}{l}\text { Joachim M. } \\
\text { Baehring, } \\
\text { MD, DSc }\end{array}$ & $\begin{array}{l}\text { Department of Neurology, } \\
\text { Yale School of Medicine; } \\
\text { Department of Neurosurgery, } \\
\text { Yale School of Medicine, New } \\
\text { Haven, CT }\end{array}$ & $\begin{array}{l}\text { Drafting/revision of the } \\
\text { manuscript for content, } \\
\text { including medical writing for } \\
\text { content; major role in the } \\
\text { acquisition of data; study } \\
\text { concept or design; and } \\
\text { analysis or interpretation of } \\
\text { data }\end{array}$ \\
\hline
\end{tabular}

\section{References}

1. Sage JI, Van Uitert RL. Man-in-the-barrel syndrome. Neurology. 1986;36:1102-1103.

2. Flanagan EP, McKeon A, Weinshenker BG. Anterior spinal artery infarction causing man-in-the-barrel syndrome. Neurol Clin Pract. 2014;4:268-269.

3. Fontanella MM, Zanin L, Bergomi R, et al. Snake-eye myelopathy and surgical prognosis: case series and systematic literature review. J Clin Med. 2020;9(7):2197.

4. Thigpen MC, Whitney CG, Messonnier NE, et al. Bacterial meningitis in the United States, 1998-2007. N Engl J Med. 2011;364(21):2016-2025.

5. van de Beek D, Brouwer MC, Thwaites GE, Tunkel AR. Advances in treatment of bacterial meningitis. Lancet. 2012;380(9854):1693-1702.

6. van de Beek D, Cabellos C, Dzupova O, et al. ESCMID guideline: diagnosis and treatment of acute bacterial meningitis. Clin Microbiol Infect. 2016;22(suppl 3):S37-S62.

7. Tunkel AR, Hartman BJ, Kaplan SL, et al. Practice guidelines for the management of bacterial meningitis. Clin Infect Dis. 2004;39(9):1267-1284.

8. Anderson TL, Morris JM, Wald JT, Kotsenas AL. Imaging appearance of advanced chronic adhesive arachnoiditis: a retrospective review. AJR Am J Roentgenol. 2017; 209(3):648-655.

9. Griessenauer CJ, Bauer DF, Moore TA II, Pritchard PR, Hadley MN. Surgical manifestations of thoracic arachnoid pathology: series of 28 cases. J Neurosurg Spine. $2014 ; 20(1): 30-40$ 
10. Hackert J, Maßmann L, Sure U, et al. Immunotherapies in chronic adhesive arachnoiditis—a case series and literature review. eNeurologicalSci. 2021;24:100350.

11. Rice I, Wee MY, Thomson K. Obstetric epidurals and chronic adhesive arachnoiditis. Br J Anaesth. 2004;92(1):109-120.

12. Eisenberg E, Goldman R, Schlag-Eisenberg D, Grinfeld A. Adhesive arachnoiditis following lumbar epidural steroid injections: a report of two cases and review of the literature. J Pain Res. 2019;12:513-518.
13. Pasoglou V, Janin N, Tebache M, Tegos TJ, Born JD, Collignon L. Familial adhesive arachnoiditis associated with syringomyelia. AJNR Am J Neuroradiol. 2014;35(6):1232-1236.

14. Nagai M, Sakuma R, Aoki M, Abe K, Itoyama Y. Familial spinal arachnoiditis with secondary syringomyelia: clinical studies and MRI findings. J Neurol Sci. 2000;177(1):60-64.

15. Jurga S, Szymańska-Adamcewicz O, Wierzchołowski W, Pilchowska-Ujma E, Urbaniak $€$. Spinal adhesive arachnoiditis: three case reports and review of literature. Acta Neurol Belg. 2021;121(1):47-53

\section{Subspecialty Alerts by E-mail!}

Customize your online journal experience by signing up for e-mail alerts related to your subspecialty or area of interest. Access this free service by clicking on the "My Alerts" link on the home page. An extensive list of subspecialties, methods, and study design choices will be available for you to choose from-allowing you priority alerts to cutting-edge research in your field!

\section{Share Your Artistic Expressions in Neurology 'Visions'}

AAN members are urged to submit medically or scientifically related artistic images, such as photographs, photomicrographs,

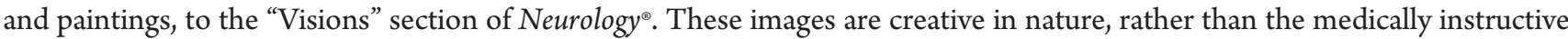
images published in the NeuroImages section. The image or series of up to six images may be black and white or color and must fit into one published journal page. Accompanying description should be 100 words or less; the title should be a maximum of 140 characters including spaces and punctuation.

Please access the Author Center at NPub.org/authors for full submission information.

\section{Visit the Neurology ${ }^{\circledR}$ Resident \& Fellow Website}

Click on Residents \& Fellows tab at Neurology.org.

Now offering:

- Neurology Resident \& Fellow Editorial team information

- "Search by subcategory" option

- E-Pearl of the Week

- Direct links to Career Planning and AAN Resident \& Fellow Pages

- Recently published Resident \& Fellow articles

- Commentaries by Editors and Resident \& Fellow team members

f Find Neurology Residents \& Fellows Section on Facebook: facebook.com/AANResidentsAndFellows

Follow Neurology on Twitter: @GreenJournal \#NeurologyRF

우 Find Neurology Residents \& Fellows Section on Instagram: @aanbrain \#NeurologyRF 


\section{Neurology}

\section{Clinical Reasoning: A 64-Year-Old Man With History of Meningitis Presenting With Proximal Weakness of the Arms}

Philipp Karschnia, Leon Kaulen, Niklas Thon, et al.

Neurology 2022;98;208-213 Published Online before print November 19, 2021

DOI 10.1212/WNL.0000000000013085

\section{This information is current as of November 19, 2021}

\section{Updated Information \& Services}

References

Subspecialty Collections

Permissions \& Licensing

Reprints including high resolution figures, can be found at: http://n.neurology.org/content/98/5/208.full

This article cites 15 articles, 3 of which you can access for free at: http://n.neurology.org/content/98/5/208.full\#ref-list-1

This article, along with others on similar topics, appears in the following collection(s):

All Clinical Neurology

http://n.neurology.org/cgi/collection/all_clinical_neurology All Epilepsy/Seizures

http://n.neurology.org/cgi/collection/all_epilepsy_seizures CT

http://n.neurology.org/cgi/collection/ct

Meningitis

http://n.neurology.org/cgi/collection/meningitis

MRI

http://n.neurology.org/cgi/collection/mri

Post-infectious

http://n.neurology.org/cgi/collection/postinfectious_

Status epilepticus

http://n.neurology.org/cgi/collection/status_epilepticus

Information about reproducing this article in parts (figures,tables) or in its entirety can be found online at:

http://www.neurology.org/about/about_the_journal\#permissions

Information about ordering reprints can be found online:

http://n.neurology.org/subscribers/advertise

Neurology ${ }^{\circledR}$ is the official journal of the American Academy of Neurology. Published continuously since 1951, it is now a weekly with 48 issues per year. Copyright (? 2021 American Academy of Neurology. All rights reserved. Print ISSN: 0028-3878. Online ISSN: 1526-632X.

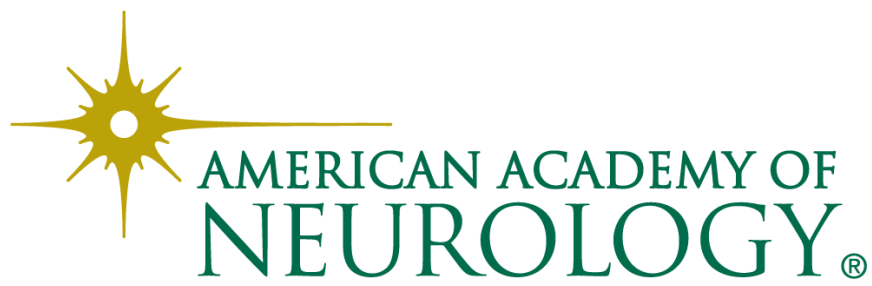

